\title{
NEWS
}

\section{Conference: Education and training}

The British Library Research and Development Department is holding an international conference in London (England) on 'New technology in the library/information school curriculum' immediately after the 7th International Online Information Meeting to be held in December 1983. It will start on Thursday, 8th December and finish at mid-day on Saturday, 10th December.

The theme will be: changes in library and information studies curricula and how to implement them. In addition to discussion of present day issues, future technological developments will be identified and discussed.

Further information can be obtained from:

Mrs. T.C. Bomford,

British Library Research and Development Department,

2, Sheraton Street,

London, W1V 4BH,

England

\section{International courses/Seminars}

(1) The eleventh International Graduate Summer School in Librarianship and Information Science, organised by the College of Librarianship Wales, in association with the University of Pittsburgh School of Library and Information Science, will take place in Aberystwyth from 27 June-20 August 1983. The following courses will be offered: micrographics; information services; problems in information science; statistical analysis for library management and research; information systems design; computers and the automation of library systems; searching subject retrieval systems; international aspects of children's literature; medical librarianship - current developments.

Further details can be obtained from:

Course Secretary, IGSS 1983,

College of Librarianship Wales,

Llanbadarn Fawr,

Aberystwyth,

Dyfed, SY23 3AS,

Wales, U.K.

0167-8329/83/\$03.00 @ 1983 North-Holland 
(2) An International Seminar for Advanced Information Work will be held in Graz and Vienna, Austria, 9 May-3 June, 1983. It will be organised by Unesco, Division for the General Information Programme, the Austrian Federal Ministry of Science and Research, and the Austrian Federal Chancellery, and will follow the principles and aims of a sequence of courses presented so far: three times in Great Britain by the University of Sheffield, Postgraduate School of Librarianship and Information Science, once in France, by the Institut d'Etudes Politiques de Paris, and twice in Austria.

The purpose of the course is to introduce new developments and advanced modern practices in information and library sciences to teachers and persons involved in training and education programmes in library and information studies especially to those from developing countries. Membership will be limited to 25; several scholarships will be available to cover all or part of the seminar fees and travelling costs. The programme will include: computing and telecommunication in information handling, information retrieval, management of library and information organisations, and visits to significant operational units.

The course will be held in English. Application forms and further particulars may be obtained from:

\author{
Mrs. A. Schurek, \\ Division for the \\ General Information Programme, \\ Unesco, \\ 7 Place de Fontenoy, \\ 75700 Paris, \\ France
}

\author{
H. Schlager, \\ Federal Ministry of Science and \\ Research, \\ Austrian Secretariat for UNISIST, \\ Minoritenplatz 5, \\ 1014 Vienna, \\ Austria
}

\section{Research in librarianship and associated topics}

Current Research in library and information science is the new title of Radials Bulletin. It offers a unique current awareness service for those who need to keep abreast of research and development work in librarianship, information science, archives, documentation and the information aspects of other fields.

Each entry provides a complete overview of the project, the personnel involved, duration, funding, references, any qualification sought, a brief description and who to contact. Full name/organisation and subject indexes are included.

The following features have been added:

(1) Directory of developments and services:

lists organisations and services which do not themselves undertake or generate research, but are of interest to library and information research workers.

(2) List of student theses and dissertations: short-form entries for pre-doctoral academic work.

(3) International coverage:

relevant research projects undertaken outside the UK are now included, in English, in the main section. 
The information provided by Current Research forms an integral part of the FID (Federation Internationale de Documentation) Research Referral Service.

Publication is quarterly, March to December. The December issue is cumulative, listing all current projects and those completed in the past year.

Current Research should be available on magnetic tape, on-line (DIALOG and ORBIT) as well as in conventional hard-copy format by mid-1983.

\section{Subscription.}

UK: £65.00; Overseas (excluding N. America): £78.00; N. America: US \$172.00.

Notes for contributors.

Contributions to Current Research are invited from all over the world. Academic work should be at doctoral or post-doctoral level. In-house or action research from practising librarians/information workers is also included. 'Research' is used in its widest sense, to include investigations, studies, surveys and evaluative investigations.

Contributions should be provided in English, on the standard Current Research forms. These are available from your national contact centre, or from:

The Editor of Current Research,

The Library Association,

7 Ridgmount Street,

London, WC1E 7AE,

England.

Tel. (01) 636 7543; Telex. 21897 LALDN G

\section{New Journal: Journal of Library Training and Education}

The Library Education Group of the Library Association (Great Britain and Northern Ireland) will adopt the new title 'Training and Education Group' from January 1st, 1983 and will begin publication of the Journal of Library Training and Education. The first issue of the new journal is scheduled for Spring 1983.

\section{Teaching aids}

How to use Biological Abstracts - Tape / Slide

'How to use Biological Abstracts' (consists of 65 slides, colour, 2" $\times 22^{\prime \prime}$ with 20 minute audio cassette and 14-page guide). The focus of the presentation is solely on the printed indices and no mention is made of the availability of on-line computer access to this information. 
It was prepared by Eva S. Jonas and is available for $\$ 115$ from:

The Librarian,

Museum of Comparative Zoology, Harvard University, 26 Oxford Street,

Cambridge, MA 02138,

U.S.A.

\section{Microcomputing}

'Microcomputing' (6 filmstrips, colour with accompanying cassettes, guide, and computer programs, Adrian Vance Publications, 1982) is one of a series consisting of six units each of which has an accompanying computer program on cassette that can be run on an Apple II computer. The first two units 'Getting Started' and 'Disks, Drives, and DOS' present basic information from selecting a microcomputer to hookup and use of tape and disk inputs. The remaining four units 'Graphics and Games', 'Applications' Programs', 'Information Systems' and 'The Software Question' deal with specific applications.

The unit on 'Information Systems' contains a description on accessing the Dialog Information Services System and an explanation on using the program for data manipulation. This unit also contains the program 'Correlation Coefficient' to enable the user to perform some simple data manipulation tasks.

'Microcomputing' is available as a complete set, for $\$ 145$ from:

Adrian Vance Productions,

P.O. Box 49210,

Los Angeles, CA 90019,

U.S.A.

\section{Computer basics}

The series 'Computer Basics' (6 filmstrips, colour, with accompanying audio cassettes and guides, Adrian Vance Productions, 1981) consists of units 'What is a Computer?', 'Do you need a Computer?', 'How to use a Computer?', 'How do Computers work?', 'How to program a Computer?' and 'What do Computers mean?'. Each individual unit is approximately 15 minutes and can be used as a self-contained unit. The information presented in most of the series is introductory, and shows the place of computers in today's society. The series is for the novice in computers and computer usage.

'Computer Basics' can be purchased for $\$ 145$ from Adrian Vance Productions (see above). 


\section{Vacancies for lecturers}

There will be several vacancies for lecturers in librarianship at the beginning of 1984 in Papua New Guinea. Further details are available from:



\section{Some recent periodical articles on education and training}

The International Library Review 14 (4) (1982) contains a number of interesting articles

- UNESCO's work in the field of library education and training, by M. Kereztesi. pp. 349-362.

- Library education and training: at home or abroad, by M.C. Lundu. pp. 363-378.

- The international role of library consultants, by E.R. Dyer and P. Layzell Ward. pp. 379-390.

- Manpower shortage and education for librarianship in Jordan, by A. Younis. pp. 417-426.

Another recent article is: Unesco journal of information science, librarianship and archives 4(3) (1982)

- Education for information and library work in New Zealand, by R. Cave. pp. 177-184.

There are two brief articles on Poland and the Federal Republic of Germany in Library and Information Research News 5 (19) (1982)

- Research activities at the Chair of Library Science of the University of Cologne, by D. Rusch. pp. 18-21.

- Library and information science education and research in Poland, by $\mathrm{J}$. Kolodziejska. pp. 13-17. 